\title{
Think-Pair-Share for Novice English Readers: Engaging Seventh Graders to Explore Narrative Text
}

\author{
Binti Roifatus Siam ${ }^{1}$, Rohmani Nur Indah ${ }^{2}$ \\ 1) Institut Agama Islam Negeri Kediri \\ 2) Universitas Islam Negeri Maulana Malik Ibrahim Malang \\ 1) bintiroifatussiam040198@gmail.com \\ 2)indah@bsi.uin-malang.ac.id
}

\begin{abstract}
Many studies have discussed the Think-Pair-Share strategy to increase students' learning motivation in various scientific fields, especially in learning English. However, it still requires more exploration concerning TPS implementation for seventh-grader students to improve their proficiency when engaged in narrative reading. This research departs from the student's opinion about the struggle to read and understand the narrative text, and the class was so boring. Therefore, it is assumed that the use of TPS can increase the student's motivation in reading narrative text. The design chosen is classroom action research (CAR) implemented at MTs. Darul Hikmah Jabon. The participants were 26 students. This research is done with one pre-cycle for need analysis and two cycles to see the increase of the student's score. In the pre-cycle, only three students reached the success criteria. In the first cycle, the scores did not significantly increase; only eleven students succeeded. In the second cycle, twenty-three students showed improvement. It resumed that the TPS technique is very effective for increasing student motivation on reading narrative text.
\end{abstract}

Keywords: Think-Pair-Share, Narrative Text, Classroom Action Research.

\section{INTRODUCTION}

The interest of students in Indonesia in reading and understanding text is classified as concerning. UNESCO data (2017) said that Indonesian teenagers' reading interest has not been above $50 \%$, which means that not half of the Indonesian teenagers have a penchant for reading. Students' reading levels are poor. Some students tend to avoid reading activities, although it looks simply. However, in English learning, reading is one of the basic skills mandatories to be taught.

In learning English, it is undeniable that productive mastering skills like speaking and writing are supported by the receptive skills of listening and reading. It becomes the basic rationale that mastering reading skill is also a must for those learning English as a foreign language. A new challenge arises for Indonesian students to improve their reading skills in English 
because it is a foreign language and not used as a colloquial language.

Reading, in general, is an activation to get information. It will further lead to a new insight. Accordingly, students are facilitated in enlarging knowledge and accessing information technology through reading. Reading is what people see in the text and associate it with the symbols written in the text (Aebsold and Field, 1997). Another expert, Heath (1983), states that reading is a very strong activity because it includes understanding, perspective, knowledge, and great insight into the reader. People who grew in families who read less often had very different views on the value of reading. This activity generally includes readers, texts, and interactions between readers and texts.

Reading skills are active mental activities and processes for understanding literal and implied meanings. According to Daiek and Anter (2004), this activity involves several phases and understanding of comprehending details, common ideas, and concluding. In other words, the readers involve a complex cognitive process ranging from obtaining information, understanding the content, interpreting its message, and evaluating the gist. Therefore, reading is not merely a passive process, as it demands the reader's active engagement with what is communicated by the text.

Wallace (1992) explains that reading has three primary purposes. The first is reading to survive. Reading survival serves an urgent need. Next is, reading for academic involvement that is related to school. Third, reading is meant to support learning. In this case, readers are required to grasp the meaning in the text not only literally or metaphorically but also to identify the structures and use text as a model for their writing. Another purpose is reading for fun or pleasure to get happiness. Readers can enjoy the text, for example, in reading narrative text.

Based on observations, interviews, and questionnaires in pre-research at Mts. Darul Hikmah Jabon, many students think reading is the most challenging part of learning English because they have several issues regarding understanding the gist of English texts. In addition, their motivation to participate actively in reading activities is low. Some students also show less enthusiasm and interest in learning to read as if it is a big burden. Furthermore, they seemed drowsy and uninterested while the teacher was explaining in front of the class. Most students still find it difficult to understand the text as a whole when discovering many new lexicons. In addition, most of the students are quiet during the class, and when the teacher asks something, they remain quiet.

Most students like English lessons, but it does not become the direct support to solve their problems in reading English texts. Teachers are already doing the teaching and learning process, but some students feel not motivated in the classroom during the teaching process. The question that arises is how TPS techniques using narrative text can improve the reading skills of 
the seventh-grade students of Mts. Darul Hikmah Jabon. Further, the purpose of this research is to find out whether TPS techniques using narrative text can improve the reading ability of the seventh-grade students in the school.

In terms of benefits, two sides arise from this research. The first is in terms of theory. The result of this research is expected to contribute to the dynamic of research finding on English teaching and learning, particularly in narrative reading skills. While practically, this research is useful for English teachers. Employing the offered strategy in this study, it is expected that teachers gain new experience in their process of teaching reading narrative text. Likewise, students can improve their skills in reading on their own since this strategy can enhance the reading experience to understand various English narrative texts.

In learning, teachers must determine strategies that are suitable for the class to meet students' needs and interests. So, hopefully, students will enjoy the learning process and can achieve the specified targets. Appropriate teaching strategies will also increase students' interest in studying the reading materials. Same as the teaching reading process, it is a must for teachers to find an appropriate strategy to keep students on track and mood for learning, understanding, and finally can improve their reading skills.
By looking at the difficulties students have in learning to read English, and they're being passive during the reading class activities, it is evident that students need an exciting new method of learning English reading that is considered effective. Therefore, think-pair-share is chosen as a potential learning method because several previous studies claim that TPS can improve students' reading skills.

The Think-Pair-Share strategy is intended for use in teaching and learning English, including reading narrative texts. It also helps create an enjoyable environment where teachers maximalist teaching reading experiences. TPS can also increase student engagement and encourage them to participate in classroom activities actively. Thus, it also can improve the communication between teachers and students and active engagement between students in the class reading activities.

So far, many types of research in various fields show the success of TPS. For example, a study conducted by Cooper (2021) in San Francisco implemented TPS in a small class of 20 students. After performing the procedure, it showed the many benefits that can occur because of the TPS method. For example, students show feelings of confidence, comfort, and reducing anxiety that often arises in students when asked to express an opinion. The same thing is also put forward by Ganatra (2021) that TPS using the storytelling method shows the effectiveness and can be applied to help medical 
students understand the materials in clinical learning.

Various local Indonesian researchers have also discussed TPS in various fields. Taking the example of research by Ribut (2021) shows that with TPS, students find it easier to overcome the difficult feeling of doing mathematics. Fauzi (2021) uses TPS to examine students' critical thinking, with the fundamental question of whether critical thinking can be improved by using TPS. Then Meilana (2021) applies TPS to elementary school students to see the improvement of students' critical thinking skills.

Looking at various previous research, there is still minimal research that further examines the use of TPS to read using narrative text as a medium. So, why is the narrative text being written as a medium? Because the narrative text is a fun text to read so that when the TPS method is applied, students will enjoy the learning process since the human brain likes fun things when learning.

Furthermore, Think-Pair-Share is a cooperative strategy that allows students to think of an idea or can be called "food for thought," the idea must be thought of first before discussing with the partner and finally shared with the classmates. This is a learning strategy developed by Lyman et al. (1988) to encourage students' participation in the classroom. Instead of the classic reading style where a teacher asks a question, and one student provides an answer, TPS encourages high student response rates and helps students focus on the task at hand.

Think-pair-share is a collaborative discussion strategy following these three steps: (1) the teacher asks the student's thoughts through questions or observations. Then students are asked to ponder a question or topic for a few minutes. (2) Connect a pair of students using the nearest designated partner to discuss each other's answers. They compare their arguments or notes and identify the answers they consider the best, most convincing, or most unique. (3) Share: After students have talked in pairs for a few minutes, the teacher asks them to share their thoughts in pairs or individually with the whole class.

According to Ledlow (2001), Think-pairshare is a low-risk strategy for engaging large numbers of students in learning. According to him, the definition of Think Pair Share is as follows. Thinking, students think independently as they ask questions and form ideas. In pairs, students discuss their ideas. On this part, students may formulate their thoughts while exploring others. Sharing, each pair of students shares an idea with a bigger cluster, for example, the entire class. It is often more convenient for students to present their ideas in groups with the support of a partner. Students' ideas were also enhanced through the three-step process described above.

According to Kagan (2006), the technique for implementing a communication strategy starts with having students count from one to 
four. Then present a topic for discussion or a problem to be addressed. After that, the teacher gives students at least ten minutes to think about their answers. This is because research shows that allowing "time to think" significantly improves the quality of student responses. Then, students work in pairs to discuss a topic or solution. Finally, a small random number of students are asked to share their ideas with the class.

According to Robertson (2006), there are several goals of communication strategies. Sometimes teachers in class convey a lot of information to students that make students less understand the material so that the information conveyed is much disappeared. By using the think-pair-share method, students will be able to sort and choose important information and inevitably have to understand the new information. Also, with TPS, students can correct previous knowledge if there is a misunderstanding in understanding the material. Once students can understand the material correctly, it will grow students' confidence feeling to participate in conveying the idea and expressing it to their classmates. Last but not least, the pairing strategy becomes easy to use in large classrooms. It has many benefits for both learners and teachers.

According to Bell (1998), using the ThinkPair-Share technique, students are given time to think more carefully about the answers that students think are the most correct before the discussion continues. Students are also allowed to think more about the ideas they think before finally being asked to share their ideas with classmates. That way, classmates have the opportunity to share the ideas that are in their heads and can increase participation in the classroom. As a collaborative learning strategy, Think-Pair-Share also benefits learners in areas such as peer recognition, peer support, academic achievement, self-esteem, and increased interest in other students and schools.

As for teachers, according to Bell (1998), the TPS technique is easy. It does not require a lot of preparation time. Then, the teacher can assess to observe the progress of students' understanding by listening to several groups during the activity and gathering responses at the end.

\section{METHOD}

In this study, the data taken came from the class of 7 Mts. Darul Hikmah Jabon, which is 26 students. The data that can be derived from pre-cycle, cycle 1 , and cycle 2 , in each cycle, contains the same steps: planning, action, observation, and reflection. This research design is collaborative classroom action research (CAR). Reading narrative text is executed during the implementation of collaborative classroom action research (CAR) by following the model of Kemmis and Taggart. In this study, the researchers collaborated with collaborator teachers, researchers as teachers, and teachers as observers. It is intended so that the chosen study strategy runs well and follows expectations (Kemmis et al., 1988). 
Applying the research cycle, the step starts with planning which means the considerations made before classroom action research begins. The teacher chooses the handbook to be used and does planning. When doing planning, the researchers paid attention first to the environment of the school, and the curriculum applied. So, when this planning has entered into action, it does not face obstacles. The next is the observation aiming to find out information after the implementation of the planning. Students' responses, attitudes, and problems that arise during research became the data. All these things must be collected to be material for the next step of reflection. So, observations should be done carefully. The last is the reflection which is the process of feedback from actions that have been done before. Reflection is used to help teachers make decisions. It has aspects to evaluate the effects of a broad problem and suggest solutions.

The researchers use two ways to collect data first by quantitative and then using qualitative. Quantitative data is used to calculate data in the form of numbers, while qualitative data is used to explain existing data in the form of sentences so that it could gain a complete understanding of the state that occurs. In collecting quantitative data, the researchers conduct reading tests. This test is given in orientation cycles one and two. Research instruments are observations, interviews, reading tests, notes, and documentation.
Before the data collection procedure begins, the researchers must know the levels of students' vocabulary level. The procedure of gathering research has held a test that lasts for four meetings.

In conducting action research, four steps include planning, action, observation, and reflection. Cycle 1 and cycle 2 are the same, starting with planning to prepare everything related to the action in the teaching and learning process. The activities are done in planning cover conducting pre-tests as an instrument to know the student's basic skills in understanding the narrative text. Then, prepare and create the media needed during teaching and learning. Next, prepare and design vocabulary materials to be used during the cycle that refer to used textbooks or other relevant textbooks. Next, prepare interview sheets, questionnaires, and observations used to find out the reactions and conditions of the student's overall class and see the developments that have existed since applying vocabulary achievement. No less important, determine collaborators who will help the researchers conduct research, analyze weaknesses in the learning process, and reflect the results of the teaching and learning process.

The next step is implementation. In this step, the researchers must do the things that have been listed in the planning. This research must be flexible because the circumstances in school can change, so that the researchers must be able to accept any changes that may occur 
and make decisions quickly. The core of this activity is to do everything on the planning.

After the implementation of the plan is observations made to record the process during the teaching and learning process. In addition, to provide the understanding and improve student learning outcomes towards the material provided. Observations are made in the classroom and as the teaching and learning process progresses from behavior, attitudes, diary notes, analyzing classes, and writing down all the actions that occur in the classroom. This is done to find out students' interest in learning to read by using TPS techniques and to find out the influence of TPS techniques in improving students' reading skills. The last is reflection, namely by evaluating the teaching and learning process, evaluating what has been done.

\section{RESULT AND DISCUSSION}

The pre-cycle identified how the level of understanding of students in reading text narrative by giving students a pre-test about the narrative text. Steps are done by the four steps mentioned above. When collecting test results, most students say that they do not understand the questions asked on the test. After the data is collected and analyzed, the following appears.

Table 1. Pre Test

\begin{tabular}{lcc}
\hline \multicolumn{1}{c}{ Criteria } & Students & Percentage \\
\hline Successful & 3 & $8 \%$ \\
\hline Unsuccessful & 23 & $92 \%$ \\
\hline
\end{tabular}

Table 1 shows how poor is the ability of students to understand the narrative text. From
26 students, only three students are considered successful, and twenty-three are unsuccessful students. It means that student reading ability is very basic. Student grades in pre-cycle are still inadequate and unsatisfactory. The researchers realize that most students still have difficulty reading and texting.

After knowing the results of the student's pre-cycle is relatively low, then carried out cycle 1 with the same four steps, namely with planning that contains preparing lesson plans, facilities, and methods to be used and preparing post-test 1. In action, it is carried out by starting learning, telling students the results of pre-tests, introducing TPS techniques to students and dividing students into pairs, etc. A detailed explanation of how the TPS procedure has been mentioned in the introduction. After observation in the cycle, one student showed fairly good participation in reading narrative text. The next step is to give students post-test 1 , which after the following analysis is the data displayed.

Table 2. Post Test 1

\begin{tabular}{lcc}
\hline \multicolumn{1}{c}{ Criteria } & Students & Percentage \\
\hline Successful & 11 & $41 \%$ \\
\hline Unsuccessful & 15 & $59 \%$ \\
\hline
\end{tabular}

Table 2 showed a good improvement in the score of the students compared to the pretest, eleven successful students, and fifteen unsuccessful students. Based on the above problems, the researchers conducted cycle two to improve students' reading skills. 
In cycle 2, the main goal is to improve even more student scores from cycle 1. Planning is focused on learning mistakes or obstacles that arise from cycle 1 . The researchers motivate students to support them to be better at reading texts. TPS technique was introduced to make them understand the procedure. The researchers have applied TPS techniques in the teaching and learning process and have performed all the procedures mentioned in the planning step.

After evaluating student readings consisting of 15 multiple-choice items, it was found that student scores showed betterment. Based on their observations and test results, the researchers concluded that the students significantly improved their reading using TPS techniques.

Table 3. Post Test 2

\begin{tabular}{lcc}
\hline \multicolumn{1}{c}{ Criteria } & Students & Percentage \\
\hline Successful & 23 & $88 \%$ \\
\hline Unsuccessful & 3 & $12 \%$ \\
\hline
\end{tabular}

Table 3 shows those twenty-three successful students and three unsuccessful students. It could conclude that students' ability to read narrative texts is greatly improved. Therefore, the problems that are generally faced by students have been resolved and can be overcome by using TPS strategies. In addition, TPS strategies can improve students' ability to read and understand the narrative text. In addition, TPS can overcome the problem of students feeling bored and not interested in learning. It can be seen that student scores increase from pre-test to post-test two.

Of the overall meetings conducted during the research, from pre-test and cycle 1 there has been an increase, although according to researchers, it has not been maximal. Therefore, after conducting cycle 2 , the significant improvement can be seen in table 3 . That's because the teacher controls the class better. Using strategies can affect teaching outcomes. In cycle 2 , many media are considered appropriate can be used to improve students' abilities during the learning process. When a teacher teaches in front of a class, a teacher should choose what kind of strategy and the appropriate media is used so that students enjoy the learning process and understand the material well.

The results of the findings show that the technique of think-pair-share can be used to make students more motivated to be interested in learning narrative text. It affects a significant increase in value even though it must be done some time cycle. It is under the initial purpose of the research. The researchers realize that TPS in addition to increasing student learning motivation. There are also some positive and negative things that students experience.

Of course, all techniques applied have advantages and disadvantages. The advantages of TPS techniques can make students more courageous to argue. As noted by Cooper (2021) noted that TPS techniques can help students have opinions, confidence, and think critically. Also, students are more confident when asked to 
read narrative text aloud. In addition, the thing that most researchers realize is that students find it easier to solve problems. Some students have a side where although they find it difficult to understand the material, they are reluctant to ask and consult the teacher about their problems. Some reasons can occur, such as they are afraid of being booed, afraid of the teacher, very unable to understand the narrative text to be confused to ask which one, and embarrassed as seventh-grade students who do not know too well their classmates. It turns out that this is in line with research conducted by Meilana (2021) that TPS can help elementary school students in fighting complicated feelings when doing math. This technique also makes it easier for teachers because as long as students are discussing with their partners, the teacher can start preparing for the next step.

But behind that, some things are less effective when using TPS techniques, namely the presence of passive students. Such students rely only passively on their partners to solve problems and complete any given tasks. In addition, it was difficult to see the progress of each student whether they had reached the level of understanding during the process. It led the researchers to whether TPS techniques would be troublesome if implemented in large classes with large numbers of students. This technique also requires several cycles until finally, the student scores show an increase.

Completing two cycles in this research has resulted in an improvement. However, if some students do not show increasing scores, it needs another cycle. Another limitation of this study is the type of reading text. This research only focuses on reading for seventh graders focusing on narrative text with TPS techniques.

\section{CONCLUSION}

This research stems from students' feelings of boredom towards English learning and low motivation to read narrative text. Because of the low motivation to learn, students find it challenging to understand the narrative text. So TPS was chosen as a new strategy to determine whether it can help students increase students' motivation and understanding in reading narrative text. As it turns out, this research shows significant results in using TPS strategies to increase the interest of seventh graders to read narrative texts. Also, the TPS strategy can make seventh-graders enjoy their engagement in narrative reading activities. The increasing interest of students and the feeling of enjoying the learning process also impact the increase in student scores in every test conducted.

This research is significant considering that reading is one of the skills that must also be learned by students, and the context EFL for Indonesian students makes teaching reading another level of complexity. Because students must be able to read and understand the content of the reading, this research can help all teachers in various aspects of science who want to increase student motivation in learning. More specifically, this research is beneficial for English 
teachers of Madrasah Tsanawiyah of seventh grade who have diverse backgrounds in English and face difficulties in teaching narrative text reading. In the future, it is expected that there will be further research on TPS on other skills such as speaking, writing, and listening to narrative text. The next researcher can also take advantage of other types of text taught, such as exposition text or text procedure.

\section{ACKNOWLEDGEMENT}

The researchers thank the principal and English teacher in Mts. Darul Hikmah for the support during the research process.

\section{REFERENCES}

Aebersold, J. A, and M.L. Field. (1997). From Reader to Reading Teacher: Issues and Strategies for Second Language Classroom. Cambridge: Cambridge University.

Barokah, A. R., \& Raharja, S. (2021, March). Improving learning motivation and the ability to organism categorize with Think Pair Share learning model. In Proceedings of the 6th International Seminar on Science Education (ISSE 2020) (Vol. 541, pp. 845852).

Bell, J. (1998). Improving Student Learning and College Teaching. Ideas on Lecturing from a Variety of Places and People, Ideas on Cooperative Learning and the Use of Small Groups: Howard Community College.

Cooper, K. M., Schinske, J. N., \& Tanner, K. D. (2021). Reconsidering the share of a thinkpair-share Emerging limitations, alternatives, and opportunities for research. CBE-Life Sciences Education, 20(1), fe1.

Daiek, Deborah and Nancy Anter. (2004). Critical
Reading for College and Beyond. New York: McGraw-Hill. P. 5.

Fauzi, F., Erna, M., \& Linda, R. (2021). The effectiveness of collaborative learning through techniques on group investigation and think pair share students' critical thinking ability on chemical equilibrium material. Journal of Educational Sciences, 5(1), 198-208.

Ganatra, S., Doblanko, T., Rasmussen, K., Green, J., Kebbe, M., Amin, M., \& Perez, A. (2021). Perceived Effectiveness and Applicability of Think-Pair-Share Including Storytelling (TPS-S) to Enhance Clinical Learning. Teaching and Learning in Medicine, 33(2), 184-195.

Heath, S. B. (1983). Ways with Words: Language, Life, and Work in Communities and Classroom. New York: Cambridge University Press.

Hendri, B. F., Rahman, I., \& Ardilla, F. (2021). Penerapan Teknik Think Pair Share Berbasis Model PjBL Dapat Meningkatkan Pengetahuan Dan Hasil Belajar Siswa SMA Negeri 2 Pariaman terhadap Keterampilan Memproduksi Teks Eksposisi. JKIP: Jurnal Kajian IImu Pendidikan, 2(1), 11-17.

Kagan, S. (2009). Kagan Cooperative Learning, San Clemente Kagan Publishing.

Kemmis, S. and R. Mc. Taggart. (1988). The Action Research Planner. Victoria: Deakin University.

Ledlow, S. (2001). Using Think-Pair-Share in the College Classroom, Center for Learning and Teaching Excellence: Arizona State University.

Lyman, F. (1988). Strategies for Reading Comprehension Think-Pair-Share. Cooperative Learning Community. Jones, Raymon C. Reading Quest. 
Meftah, S. (2021). An Investigation into The Effectiveness of Using Think-Pair-Share Strategy on Improving English as a Foreign Language Student's Paragraph Writing The case of third-year students of English at Biskra University.

Meilana, S. F., Aulia, N., Zulherman, Z., \& Aji, G. B. (2021). Pengaruh Model Pembelajaran Think Pair Share (TPS) terhadap Kemampuan Berpikir Kritis di Sekolah Dasar. Jurnal Basicedu, 5(1), 218-226.

Ribut, O. (2021). Pengaruh Model Pembelajaran Kooperatif Think Pair Share (TPS) Pada Prestasi matematika Siswa Sekolah Menengah Pertama. Jurnal Jendela Pendidikan, 1(1), 1-6.

Riyadi, S. (2021). Implementasi Metode Think Pair Share Pada Materi Membiasakan Toleransi Dan Menghindari Tindak
Kekerasan Pada Siswa Kelas XI SMA Ekasakti Padang. Journal of Social And Economics Research, 3(1), 009-020.

Robertson, K. (2006). Increase Students Interaction by Think-Pair-Share Technique. Mexico City: Colorin Colorado.

Satria, H. (2021). Pengaruh Teknik Cooperative Learning Berbasis Metode Think Pair Share Untuk Meningkatkan Pemahaman Materi Dasar-Dasar Elektronika. CIRCUIT: Jurnal IImiah Pendidikan Teknik Elektro, 5(1), 1723.

UNESCO. (2017). Literacy Rates Continue to Rise from One Generation to the Next. Retrieved from http://uis.unesco.org/en/topic/literacy

Wallace. (1996). Reading. New York: Cambridge University Press. 